\title{
Pengaruh Perbedaan Konsentrasi Pupuk Organik Cair tehadap Produksi Bawang Merah (Allium ascalonicum L)
}

\author{
Setiyowati, Sri Haryanti dan Rini Budi Hastuti \\ Laboratorium Biologi dan Struktur Fungsi Tumbuhan FMIPA Undip
}

\begin{abstract}
Shallot is one an important of vegetable comodity, both in economic value and nutrition ingredients. One of an effort to support the increasing of shallot yield with plantation technology by giving organic liquid fertilizer. The experiment we studied to find out the effect of organic liquid fertilizer with different consentration on yield of shallot. The experiment used Completely Randomized Design consisted 6 consentration of organic liquid fertilizer 0 $\mathrm{ml} / \mathrm{L}(\mathrm{P} 0), 1 \mathrm{ml} / \mathrm{L}(\mathrm{P} 1), 2 \mathrm{ml} / \mathrm{L}(\mathrm{P} 2), 3 \mathrm{ml} / \mathrm{L}$ (P3), $4 \mathrm{ml} / \mathrm{L}$ (P4), $5 \mathrm{ml} / \mathrm{L}$ (P5) with 4 replication. The results show that consentration of $4 \mathrm{ml} / \mathrm{L}$ organic liquid fertilizer is increas the number of bulb and consentratin of $5 \mathrm{ml} / \mathrm{L}$ is increas in tuber wet weight.
\end{abstract}

Key words : organic liquid fertilizer, production, shallot

\begin{abstract}
Abstrak
Bawang merah merupakan salah satu komoditas sayuran yang mempunyai arti penting, baik dilihat dari nilai ekonomisnya yang tinggi maupun kandungan gizinya. Salah satu usaha untuk menunjang peningkatan produksi bawang merah adalah melaui teknologi budidaya dengan pemberian pupuk organik cair. Tujuan penelitian ini adalah untuk mengetahui pengaruh pupuk organik cair terhadap produksi bawang merah dengan konsentrasi yang berbeda. Penelitian ini menggunakan Rancangan Acak Lengkap terdiri dari 6 konsentrasi pupuk organik cair yaitu 0 ml/1 (P0), $1 \mathrm{ml} / \mathrm{l}(\mathrm{P} 1), 2 \mathrm{ml} / \mathrm{l}(\mathrm{P} 2), 3 \mathrm{ml} / \mathrm{l}(\mathrm{P} 3), 4 \mathrm{ml} / \mathrm{l}$ (P4), $5 \mathrm{ml} / \mathrm{l}$ (P5) masing-masing dengan 4 ulangan. Hasil penelitian menunjukkan bahwa konsentrasi pupuk organik cair $4 \mathrm{ml} / \mathrm{l}$ dapat meningkatkan jumlah umbi, sedangkan konsentrasi $5 \mathrm{ml} / \mathrm{l}$ dapat meningkatkan berat basah umbi.
\end{abstract}

Kata kunci : pupuk organik cair, produksi, bawang merah

\section{PENDAHULUAN}

Bawang merah (Allium ascalonicum L) merupakan salah satu komuditas sayuran yang mempunyai arti penting bagi masyarakat, baik dilihat dari nilai ekonomisnya maupun kandungan gizinya yang tinggi. Meskipun bukan merupakan kebutuhan pokok namun tidak dapat dihindari oleh konsumen bahwa keberadaaannya sebagai bumbu pelengkap sangat diperlulan karena banyak mengandung vitamin $\mathrm{B}$ dan $\mathrm{C}$. selain itu bawang merah juga digunakan sebagai obat tradisionil seperti menyembuhkan luka atau infeksi, memperbaiki pencernaan dan menghilangkan lendir di tenggorokan (Rukmana, 1994).

Bawang merah di Indonesia telah lama dibudidayakan oleh petani secara komersil, dimana sebagian besar hasil produksinya ditujukan untuk memenuhi permintaan pasar.
Usaha peningkatan produksi pertanian hortikultura tidak lepas dari peranan pupuk sebagai bahan penyubur. Hal yang mungkin belum tercapai dengan baik adalah meningkatkan efisiensi penggunaannya. Pengunaan ini perlu ditingkatkan karena salah satu faktor yang membatasi produksi tanaman adalah unsur hara. Pupuk dapat digunakan untuk mencapai keseimbangan hara bagi pertumbuhan tanaman, sehingga dapat mencapai produksi yang optimal (Setyamidjaja, 1986). Pupuk cair merupakan pupuk yang dibuat ddari bahan baku kotoran ternak, kompos, limbah alam dengan kandungan unsur hara lengkap. Pupuk ini mempunyai kelebihan diantaranya adalah memperbaiki sifat fisik, kimia dan biologi tanah, meningkatkan kondisi lingkungan yang baik untuk pertumbuhan tanaman, mengurangi dosis pemakaian pupuk 
kimia sampai $25 \%$, aman bagi petani dan ramah lingkungan.

Bawang merah selama pertumbuhannya memerlukan unsur hara seperti $\mathrm{N}, \mathrm{P}, \mathrm{K}, \mathrm{Ca}, \mathrm{Mg}$ dan Na. Unsur hara tersebut dapat diperoleh dengan pemberian pupuk organik dan anorganik. Menurut Asandhi dan Koestoni (1990) dosis pemupukan bawanng merah di tingkat petani cukup tinggi dan tanpa penggunaan pupuk anorganik. Penggunaan pupuk anorganik yang tinggi secara terus menerus jika tidak diimbangi pupuk organik akan merusak sifat fisik dan kimia tanah dan merusak kehidupan mikroorganisme tanah (Indriani, 1999).

Pupuk organik cair dapat dipergunakan untuk semua jenis tanaman hortikultura dengan konsentrasi 1-2 cc yang dilarutkan dalam $1 / 2$ sampai 1 liter air yang disiramkan lewat tanah atau daun setiap 2-4 minggu sekali (Anonim, 2000). Dengan melihat beberapa kelebihan dari pupuk organik cair ini dimana salah satunya dapat mengurangi pupuk kimia, maka perlu dilakukan inovasi teknologi pemakaiannya dengan biaya yang murah.

Sampai saat ini varietas bawang merah cukup banyak, bahkan telah menjadi tanaman likal dan berkembang di berbagai daerah misalnya Bima Brebes, Sumenep, lampung, maja, Medan, Ampenan, yang satu dan lainnya tampak perbedaaanya pada bentuk dan warnanya, ukuran, kekenyalan, aroma, umur serta ketahanan tanaman terhadap penyakit dan hujan (Samadi dan Cahyono, 1996, Rahayu dan Berlian, 1994). Kualitasnya ditentukan oleh warna merah cerah, kepadatan umbi serta bau yang sedap/harum.

Bawang merah dapat tumbuh di dataran rendah sampai tinggi yaitu 0-900 m dpl. Suhu udara yang ideal untuk tanaman bawang merah adalah $25^{\circ}-30^{\circ} \mathrm{C}$, namun masih toleran pada susu $22^{\circ} \mathrm{C}$, kelembaban udara nisbi $80 \%-90 \%$ akan memacu perkembangan produksinya. Curah hujan yang sesuai adalah 300-2500 mm per tahuun, dengan intensitas sinar matahari penuh, dengan derajad keasaman tanahnya sekitar 5,5-6,5. Angin merupakan faktor yang berpengaruh terhadap kondisi tanah dan secara tidak langsung mempengaruhi pertumbuhannya. Pada tanah yang becek pertumbuhan tanaman bawang merah akan kerdil sehingga produksi umbinya menjadi busuk.
Menurut Sutejo (1995) produksi merupakan hasil tanaman yang dapat dipanen per luasan tanah tertentu. Produksi tanaman juga merupakan biomasa yang dibentuk oleh tanaman selama masa hidupnya atau selama masa tertentu yang digunakan untuk mempentuk bagian-bagian tubuhnya. Biomasa tanaman meliputi semua bahan tanaman yang secara umum berasal dari hasil fotosintesis, serapan unsur hara dan air yang diolah melalui proses biosintesis. Pengukuran biomasa total tanaman dengan penimbangan berat basah dan berat kering tanaman merupakan parameter paling baik digunakan sebagai indikator pertumbuhan dan produksi. Selain itu bahan kering tanaman dipandang sebagai manifestasi dari semua proses dan peristiwa yang terjadi dalam pertumbuhan tanaman. Produksi bawang merah diukur setelah dilakukan pemanenan dengan parameter jumlah anakan dan berat basah umbi. Kemasakan umbi dapat dilihat dari keadaan fisik tanaman maupun umbi. Umur tanaman yang sudah dapat dipanen adalah 60-70 hari setelah tanam.

Pemupukan yang biasa dan kebanyakan dilakukan petani sampai sekarang hanya melalui tanah, sehingga unsur hara tersebut diserap oleh akar tanaman dan ditransformasi menjadi bahanbahan yang berguna bagi pertumbuhan. Sesungguhnya tidak saja akar tetapi bagian tanaman lainpun seperti daun dan batang dapat menyerap unsur-unsur yang kita semprotkan. Jadi pemupukan dapat dilakukan dengan jalan menyemprotkan pupuk melalui daun yang berbentuk cair. Masuknya unsur hara yang dikandung pupuk cair ke dalam tanaman melaui mikropores daun terutama lewat penetrasi kutikula dan stomata. Keuntungan pemupukan lewat daun adalah menghindari larutnya unsur hara sebelum didapat oleh akar, atau mengalami fiksasi dalam tanah yang berakibat tidak dapat diserap lagi oleh tanaman, absorbsi hara oleh sel daun lebih cepat dan efektif unruk menanggulangi kekurangan unsur mikro (Tisdale and Nelson, 1975).

Pupuk organik cair mengandung 13 jenis unsur makro dan mikro yang mutlak dibutuhkan oleh semua tanaman. Pupuk ini dilengkapi juga asam humat dan fulvat. Menurut Rao (1994), asam humat dan fulvat melupakan fraksi utama yang diperoleh dari humus. Asam humat membentuk bagian terbesar dari kompleks humus dan 
dianggap sebagai polimer senyawa aromatik. Asam fulvat merupakan bagian yang terlarut dari bahan organik tanah yang bersifat basa maupun asam dan mengandung karbohidrat dan protein.

\section{BAHAN DAN METODE}

Penelitian ini menggunakan rancangan acak lengkap (RAL) dengan faktor tunggal berupa konsentrasi. Penelitian terdiri dari 6 perlakuan yaitu : konsentrasi pupuk organik cair $0 \mathrm{ml} / \mathrm{l}, 1$ $\mathrm{ml} / \mathrm{l}, 2 \mathrm{ml} / \mathrm{l}, 3 \mathrm{ml} / \mathrm{l}, 4 \mathrm{ml} / 1$ dan $5 \mathrm{ml} / \mathrm{l}$. Masingmasing perlakuan dengan 4 ulangan.

Bahan bibit tanaman bawang merah diambil dari KUD Brebes varietas Bima yang telah disimpan 3 bulan dan beratnya sekitar $5 \mathrm{~g}$ per umbi. Sehari sebelum tanan bibit dipotong ujungnya untuk merangsang pertumbuhannya. Sehari sebelum tanam media pada polibag disiram pupuk organik cair masing-masing sesuai dengan konsentrasi tersebut, lalu bibit ditanam dengan cara dibenamkan. Pada saat tanaman umur 2, 4 dan 6 minggu setelah tanam dilakukan penyemprotan pada daun sesuai konsentrasi di atas dengan volume $100 \mathrm{ml} /$ tanaman. Pemupukan dengan pupuk anorganik dilakukan sama seluruh tanaman dikurangi sebanyak $25 \%$ nya dari urea 2,5 $\mathrm{g} /$ tanaman (menjadi 1,9 g/tanaman), TSP 1,5 g/tanaman (menjadi 1,13 g/tanaman), $\mathrm{KCl} 1$ $\mathrm{g} /$ tanaman (menjadi $0,75 \mathrm{~g} / \mathrm{tanaman}$ ). Perlakuan tersebut menjadi sbb :

P0 : Pupuk anorganik 75\% tanpa penmberian pupuk organik cair

Pl : Pupuk anorganik 75\% ditambah pupuk organik cair konsentrasi $1 \mathrm{ml} / \mathrm{l}$

P2 : Pupuk anorganik 75\% ditambah pupuk organik cair konsentrasi $2 \mathrm{ml} / \mathrm{l}$

P3 : Pupuk anorganik 75\% ditambah pupuk organik cair konsentrasi $3 \mathrm{ml} / \mathrm{l}$

P4 : Pupuk anorganik 75\% ditambah pupuk organik cair konsentrasi $4 \mathrm{ml} / \mathrm{l}$

P5 : Pupuk anorganik 75\% ditambah pupuk organik cair konsentrasi $5 \mathrm{ml} / \mathrm{l}$

Pemeliharaan tanaman meliputi penyiraman air dan penyiangan gulma. Pemenenan dilakukan setelah tanaman umur 60 hari. Parameter yang diamati adalah jumlah umbi, diameter umbi, berat basah umbi dan berat kering umbi. Data yang diperoleh dianalisis dengan analisis sidik ragam (anova) dan dilanjutkan dengan uji Duncan dengan taraf $5 \%$.

\section{HASIL DAN PEMBAHASAN}

Tabel 1. Rata- rata jumlah umbi, diameter umbi, berat basah umbi dan berat kering umbi bawang merah setelah pemberian pupuk organik cair.

\begin{tabular}{lcccccc}
\hline \multirow{2}{*}{ Parameter } & P0 & P1 & P2 & P3 & P4 & P5 \\
$\begin{array}{l}\text { Jumlah } \\
\text { umbi }\end{array}$ & $7,00^{\mathrm{a}}$ & $7,00^{\mathrm{a}}$ & $7,00^{\mathrm{a}}$ & $7,50^{\mathrm{a}}$ & $10,5^{\mathrm{b}}$ & $9,75^{\mathrm{a}}$ \\
$\begin{array}{l}\text { Diameter } \\
\text { umbi }\end{array}$ & $1,14^{\mathrm{a}}$ & $1,08^{\mathrm{a}}$ & $1,16^{\mathrm{a}}$ & $1,21^{\mathrm{a}}$ & $1,23^{\mathrm{a}}$ & $1,22^{\mathrm{a}}$ \\
$\begin{array}{l}\text { Berat } \\
\text { basah }\end{array}$ & $10,30^{\mathrm{a}}$ & $10,00^{\mathrm{a}}$ & $10,78^{\mathrm{a}}$ & $11,33^{\mathrm{a}}$ & $12,60^{\mathrm{ab}}$ & $14,35^{\mathrm{b}}$ \\
$\begin{array}{l}\text { umbi } \\
\text { Berat } \\
\text { kering }\end{array}$ & $6,28^{\mathrm{a}}$ & $6,68^{\mathrm{a}}$ & $7,53^{\mathrm{a}}$ & $8,10^{\mathrm{a}}$ & $9,00^{\mathrm{a}}$ & $10,60^{\mathrm{a}}$ \\
umbi & & & & & &
\end{tabular}

Keterangan : Angka rata-rata pada baris yang sama yang diikuti huruf yang sama menunjukkan berbeda tidak nyata pada uji Duncan taraf kepercayaan $95 \%$.

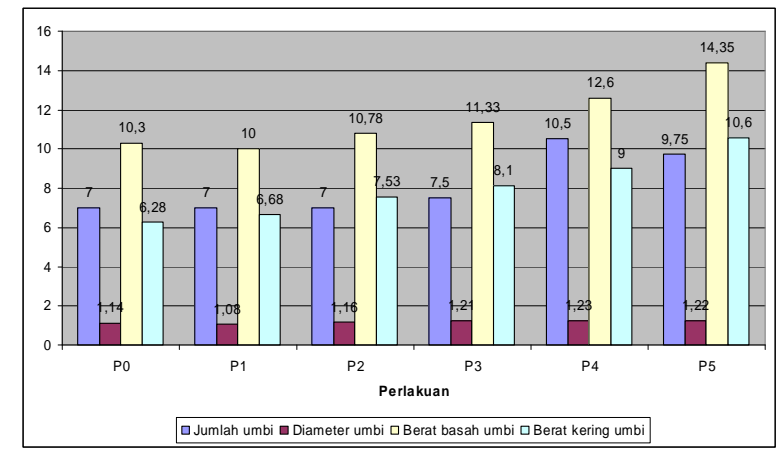

Gambar 1. : Histogram rata-rata jumlah umbi, diameter umbi, berat basah umbi dan berat kering umbi setelah diberi pelakuan pupuk cair.

Berdasarkan analisis sidik ragam terhadap jumlah umbi bawang merah setelah perlakuan pupuk organik cair menunjukkan bahwa $\mathrm{F}$ hitung $>\mathrm{F}$ tabel, hal ini menunjukkan bahwa perlakuan pupuk organik cair berpengaruh terhadap jumlah umbi. Pemberian pupuk organik cair dapat meningkatkan jumlah umbi bawang merah dan konsentrasi $4 \mathrm{ml} / \mathrm{l}$ (P4) menunjukkan jumlah umbi terbanyak. Umbi bawang merah terbentuk dari pangkal daun yang membengkak berlapis-lapis membentuk batang semu sebagai umbi lapis yang berfungsi sebagai organ penyimpan cadangan makanan. Pada discus atau batang utama yang 
pendek terdapat mata tunas yang dapat membentuk rumpun tanaman baru atau anakan. Pemberian pupuk organik cair dengan kandungan unsur hara lengkap akan memacu fotosintesis dan hasilnya yang berupa karbohidrat akan ditransport ke seluruh bagian organ tanaman. Hal ini didukung olel Dwidjoseputro (1988) yang menyatakan bahwa hasil fotosintesis akan ditransport dari daun ke bagian meristem setelah melalui respirasi yang menghasilkan ATP di titik tumbuh dan memacu pembelahan sel-sel primordia/tunas daun. Semakin banyak anakan yang tumbuh maka jumlah umbi semakin banyak.

Respon tanaman bawang merah dalam hal jumlah umbi perumpun tehadap pemupukan organik sejalan dengan peningkatan jumlah daun perumpun. Peningkatan jumlah daun perumpun ini disertai dengan penampilan daun yang berwarna hijau menandakan terjadi peningkatan kandungan klorofil yang menghasilkan fotosintat untuk pertumbuhan dan perkembangan tanaman (Limbongan dan Monde, 1999). Walaupun jumlah umbi yang dihasilkan normal seperti hasil budidaya pada umumnya yaitu 2-20 umbi, tetapi umbi dari hasil penelitian ini ukurannya kecilkecil. Hal ini dimungkinkan unsur hara dalam pupuk cair memang mendukung fotosintesis dan menghasilkan karbohidrat, tetapi karena penggunaannya dikurangi $20 \%$ dan diberikan 1 kali selama penanaman, sementara pada budidaya umumnya pemberian $100 \%$ pupuk anorganik dilakukan sebanyak 4 kali selama masa tanam sehingga dimungkinkan suplai hara sedikit dan menghasilkan fotosintat yang juga sedikit, maka pembelahan sel pada jaringan vegetatif yang terjadi tidak diimbangi dengan pembesaran sel dan hasil fotosintat yang ditimbun pada umbi sedikit akibatnya ukuran umbinya kecil. Semakin banyak jumlah daun maka tidak efektif dalam proses metabolisme, karena jika sudah masuk fase generatif tetapi pertumbuhan vegetatif masih berlangsung mengakibatkan terjadinya persaingan translokasi asimilat ke umbi atau bunga ,sehingga energi pengisian vakuola sel berkurang dan akhirnya selnya tetap kecil-kecil.

Berdasarkan analisis sidik ragam terhadap diameter umbi bawang merah setelah perlakuan pupuk organik cair menunjukkan bahwa $\mathrm{F}$ hitung $<\mathrm{F}$ tabel, hal ini menunjukkan bahwa perlakuan pupuk organik cair berpengaruh tidak nyata terhadap diameter umbi. Bentuk umbi yang kecil sangat terpengaruh pada saat perkembangannya, terutama pada energi yang dibutuhkan saat pengisian sel. Sel-sel umbi lapis mengandung vakuola-vakuola yang berisi minyak atsiri (Fahn, 1992). Minyak atsiri adalah hasil metabolit sekunder yang termasuk dalam senyawa aromatik. Akibat dari persaingan dalam memperoleh energi tersebut maka metabolisme senyawa tersebut terhambat, sehingga yang disimpan dalam sel-sel pangkal daun hanya sedikit, walaupun berlapislapis tetapi secara relatif belum dapat menambah diameter umbi secara nyata (Robinson, 1995).

Berdasarkan analisis sidik ragam terhadap berat basah umbi bawang merah setelah perlakuan pupuk organik cair menunjukkan bahwa $F$ hitung > F tabel, hal ini menunjukkan bahwa perlakuan pupuk organik cair berpengaruh terhadap berat basah umbi. Konsentrasi 5 ml/l (P5) memberikan berat basah umbi bawang merah tertinggi. Berat basah umbi merupakan berat umbi pada saat tanaman masih hidup dan ditimbanag langsung seeaat setelah panen. Beukema (1979) dalam Ruminto dan Sugandi (1988) menyatakan bahwa pembesaran umbi lapis diakibatkan oleh pembesaran sel yang lebih dominan dari pada pembelahan sel. Peningkatan berat basah umbi dipengaruhi oleh banyaknya absorbsi air dan penimbunan hasil fotosintesis pada daun untuk ditranslokasikan bagi pembentukan umbi. Jadi perbedaan kadar air akan mempengaruhi berat basah umbi yang dihasilkan. Namun berbeda dengan berat basah, berdasarkan analisis sidik ragam terhadap berat kering umbi bawang merah setelah perlakuan pupuk organik cair menunjukkan bahwa $\mathrm{F}$ hitung < $\mathrm{F}$ tabel, hal ini menunjukkan bahwa perlakuan pupuk organik cair tidak berpengaruh nyata terhadap berat kering umbi. Pada parameter berat kering umbi menunjukkan bahwa konsentrasi $0 \mathrm{ml} / 1$ (P0), $1 \mathrm{ml} / 1(\mathrm{P} 1), 2 \mathrm{ml} / 1$ (P2), 3 ml/l (P3), 4 ml/l (P4), 5 ml/l (P5) berbeda tidak nyata satu sama lain. Hal ini berarti berat kering umbi yang dicapai relatif sama. Berat kering merupakan akumulasi senyawa organik yang berhasil disintesis tanaman dari senyawa anorganik (Lakitan, 1996). Ukuran umbi yang kecil merupakan indikasi bahwa kandungan senyawa organik dalam umbi seperti karbohidrat, 
protein, lemak dan lain-lain sangat sedikit, sehingga komponen berat kering yang diperoleh juga relatif sama dan sedikit.

\section{KESIMPULAN}

1.Pupuk organik cair berpengaruh terhadap peningkatan jumlah umbi dan berat basah umbi bawang merah.

2. Konsentrasi $4 \mathrm{ml} / \mathrm{L}$ menghasilkan jumlah umbi terbanyak dan konsentrasi $5 \mathrm{ml} / \mathrm{L}$ menghasilkan berat basah uumbi tertinggi.

\section{DAFTAR PUSTAKA}

Anonim, 2000. Pupuk Organik cair Supra Alam Lestari. PT Surya Pratama Alam. Yogyakarta

Ashandi, A.A. dan Koestoni. 1990.Efisiensi Pemupukan pada Pertanaman Tumpang Gilir Bawang Merah - Cabai Merah. Bul.Penel. hort XIX

Dwidjoseputro, D. 1988. Pengantar Fisiologi Tumbuhan. PT Gramedia Jakarta

Fahn, A. 1992. Anatomi Tumbuhan . PT Gramedia Jakarta

Indriani, Y.H. 1999. Membuat Koompos Secara Kilat. Penebar Swadaya. Jakarta.

Lakitan, B. 1996. Fisiologi Pertumbuhan dan Perkembangan Tanaman. PT Raja Grafindo Persada, Jakarta
Rahayu, E. dan N. Berlian. 1994. Bawang Merah. Penebar Swadaya, Jakarta

Rao, S. 1994. Mikroorganisme dan Pertumbuhan Tanaman. UI Press. Jakarta

Robinson, T. 1995. Kandungan Organik Tumbuhan Tinggi. ITB Press. Bandung

Rukmana, R. 1994. bawang Merah, budidaya dan Pengolahan Pascapanen. Penerbit Kanisius Yogyakarta

Ruminto, A. dan E. Sugandi. 1988. Pengaruh Pemberian Konsentrasi Zat Pengatur Tumbuh Nitrofenol terhadap Inisiasi Umbi dan hasil Bawang Putih Varietas Lumbu Hijau. Fak Pertanian Universitas Satya wacana Salatiga

Samadi, B. Dan B. Cahyono. 1996. Intensifikasi Budidaya bawang Merah. penerbit Kanisius, Yogyakarta

Setyamidjaja, D. 1986 . Pupuk dan Pemupukan. CV Simplex Jakarta.

Sutejo, M.M. 1995. Pupuk dan cara Pemupukan. Penerbit Rineka Cipta. Jakarta

Tisdale, S.L. and W.L. Nelson. 1975. Soil Fertility and Fertilizers. Third Edition. McMillan Publishing Co Inc, New York. 